Ольга Викторовна Трофимова

Россия, Тюменский государственный университет

\title{
Особенности пунктуации рукописных деловых текстов (на материале тюменских архивных документов $1762-1796$ гг.)
}

Ключевые слова: пунктуация, история русского языка, грамматика, язык документа, скоропись.

Key words: punctuation, history of the Russian language, grammar, document language, cursive.

\section{Abstract}

The paper discusses Russian punctuation marks and their use in official handwritten documents at one of the initial stages of the formation of Russian punctuation system. The research material for the paper is the body of archival documents of the $18^{\text {th }}$ century and it consists of 381 documents of 82 genres.

\section{Материал исследования и постановка проблемы}

Предмет исследования - русские знаки препинания в их употреблении на одном из начальных этапов становления русской пунктуационной системы. Исследуемый материал ограничен временными, локальными и функциональными рамками. Это корпус скорописных документов, относящихся к периоду правления императрицы Екатерины II (1762-1796 гг.), вошедших в издание «Памятники тюменской деловой письменности»: 347 текстов в [Trofimova 2002a] и 34 текста - в [Trofimova 2002b].

Субъекты письма в текстах - преимущественно профессионалы, а также немногочисленные грамотные представители местного населения. Большая часть вошедших в корпус документов, в соответствии с формуляром, содержит 
реквизит «Подпись», но чаще всего в них нет сведений о том, чьей рукой текст написан. В очень редких случаях можно прочитать записи типа следующей:

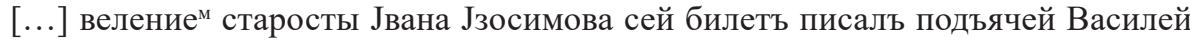
Климинъ јвместо ево рғку приложилъ [Trofimova 2002a: 19].

Субъекты устной речи, инициаторы письменной деловой коммуникации: 1) высшие должностные лица (губернаторы, воеводы, коменданты, управители и др.) - субъекты волеизъявления в ордерах, предложениях, указах и пр.; 2) подчиненные должностные лица (военные чины, старосты, целовальники и др.), докладывающие об инцидентах или фиксирующие положение дел в выборах, крепостях, обысках, описях, пашпортах и др.; 3) просители (купцы, крестьяне, мещане и пр.), от имени которых составлялись доношения, объявления, челобитные.

К лингвистическому исследованию привлекается корпус, состоящий из 381 документа, в котором отражена речевая практика субъектов речи, наследовавших и развивавших навыки русской деловой коммуникации, сложившиеся к середине XVIII в.

Документы представляют собой реализацию 82 жанров, посредством которых происходила бо́льшая часть региональной деловой коммуникации, включавшей ограниченное число участников. О специфике подобных ситуаций в актуальном для нас пунктуационном аспекте А.Б. Шапиро писал следующее:

Пока тот или иной документ $[\ldots]$ или сочинение $[\ldots]$ переписывалось от руки профессионалами-писцами и читалось немногими грамотными людьми [...], не было особой нужды в тщательном обозначении всех сторон письменного текста [...] Чтец, в силу профессиональной опытности, справлялся более или менее удовлетворительно с любым текстом - тем более, что как жанровые, так и стилистические разновидности произведений письменности были в то время не так уж многочисленны и разнообразны [Šapiro 1955: 6].

На «стыке» региональной и столичной письменной традиции деловой коммуникации побеждала региональная. В частности, если в состав выписок, экстрактов из следственных дел входили цитаты из законодательных текстов, местные канцеляристы достаточно свободно, с графико-орфографической и пунктуационной точек зрения, с ними обращались. Так, статьи из Соборного Уложения 1649 г. процитированы в пяти документах корпуса (выписки, лист о преступнике, определения) 1764-1786 гг., при этом в двух 169 статья Уложения. Сопоставив запись этой статьи в тексте-оригинале и два её цитирования в документах, составленных в Тюменской воеводской канцелярии (табл. 1), обнаруживаем: в оригинальном тексте - шесть запятых и точку в конце предложения (и статьи в целом), в первом скорописном документе - только знак :| в конце цитаты (напоминающий сроку Л. Зизания :॥ [Kuz'minova 2000: 42]), во втором - две из запятых оригинала (перед союзом 
$\boldsymbol{a}$ при противительных и союзом $\boldsymbol{u}$ при присоединительных отношениях вывода), но без финальной точки.

Таблица 1. Сопоставление фрагментов из «Соборного Уложения»

\begin{tabular}{|c|c|c|}
\hline Соборное Уложение & $\begin{array}{c}\text { Док. № } 14 \\
\text { [Trofimova 2002a: 44] } \\
\text { Выписка. } 1764 \text { г. }\end{array}$ & $\begin{array}{c}\text { Док. № } 144 \\
\text { [Trofimova 2002a: 302] } \\
\text { Определение. } 1777 \text { г. }\end{array}$ \\
\hline $\begin{array}{c}{[\text { https://dlib.rsl.ru/ }} \\
\text { viewer/01002429078\#? } \\
\text { page }=143]\end{array}$ & 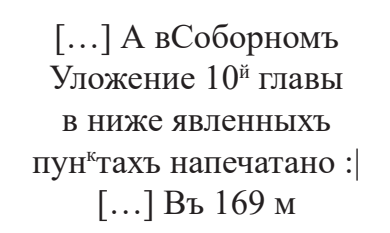 & $\begin{array}{c}{[\ldots] \text { асоборного уложен }} \\
10^{\text {же }} \text { главы во } 169^{u} \text { статье } \\
\text { напечатано }\end{array}$ \\
\hline 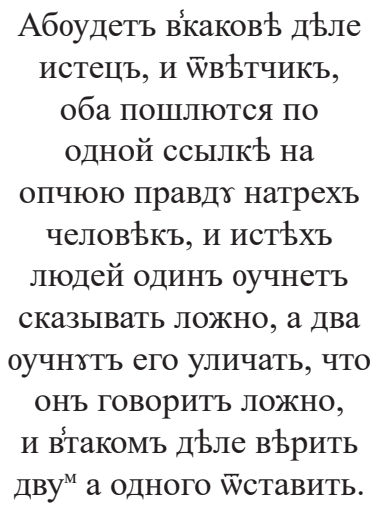 & 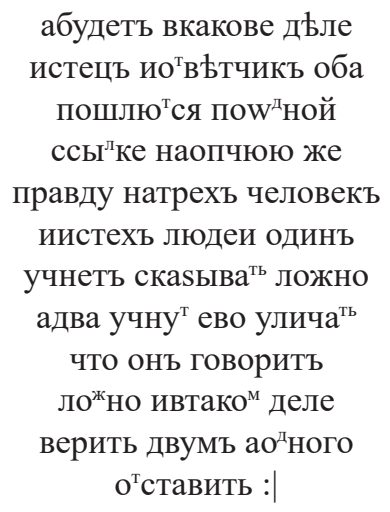 & 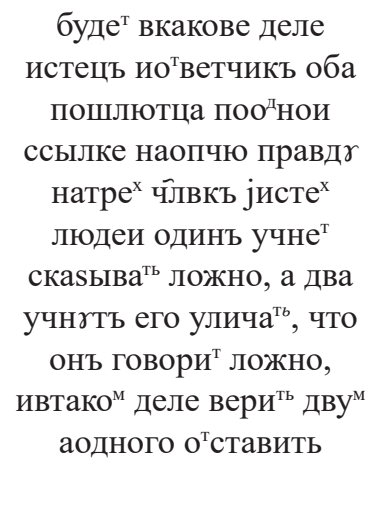 \\
\hline
\end{tabular}

Вероятно, выявленные пунктуационные различия можно считать одним из проявлений общей ситуации, сложившейся в сфере «некнижной письменности», которую В.М. Живов прокомментировал следующим образом:

Ядром этой сферы являются юридические кодексы, не потому, однако, что на них ориентированы другие некнижные тексты $[\ldots]$, но потому что они создают прецедент памятников, которые обнаруживают преемственность, но не обладают культурным престижем. [...] В дальнейшем по мере появления письменной документации регламентационная установка, присущая юридическим текстам [...], распространяется и на деловые тексты, причем выраженность этой установки зависит от социального статуса отдельных текстов [Živov 2017: 297].

В «социальном статусе делового текста» отражается и административный уровень субъектов деловой коммуникации, и жанр документа. Этот вывод вытекает, в частности, из исследования документных жанров, 
проведенного на материале тюменских документов 1762-1796 гг. в [Trofimova 2002b].

В настоящей статье функционирование знаков препинания рассматривается в диахроническом, жанровом и формулярно-грамматическом аспектах. Необходимые фоновые сведения о русской «пунктуационной ситуации», в том числе сложившейся в письменной речи к 1762 г., с учетом грамматик Л. Зизания, М. Смотрицкого [Kuz'minova 2000], В.Е. Адодурова [Uspenskij 1975], M.В. Ломоносова [Rossijskaâ 1775] и воззрений современных исследователей [Valgina 1979; Šubina 2006], мы представили в [Trofimova 2014].

\section{Количественные характеристики корпуса документов в диахроническом аспекте}

Материал исследования представляет четыре десятилетия (табл. 2). Из 381 текста корпуса 71 текст $(18,6 \%)$ не имеет знаков препинания. Больше всего таких текстов приходится на начальное десятилетие $(35,9 \%)$. Начиная со второго периода подобных документов становится меньше почти в три раза.

В документах фиксируем набор из 12 знаков препинания. Кроме 9 одинарных знаков, представленных в табл. 2, встречаются парные: в 11 документах - квадратные скобки (чаще как знак правки текста, реже - вставной конструкции), в 3 - фигурные скобки (как знак вставки), например:

[...] журналы и указы разобраны жъ по годомъ по месецамъ и числамъ и переплетены и содержатся ныне в Тюменскоі воеволскои канцеляриі в тои же светлице в которои исправление дела ${ }^{\mathrm{M}}$ чинјтца \{по малости онои и по невозможности постави $^{\text {ть }}$ во оную для содержания дель шкафо ${ }^{\text {в }}$ на полка ${ }^{\mathrm{x}}$ [Trofimova 2002a: 24].

Материалы табл. 2 показывают, что частотность каждого из знаков препинания на протяжении исследуемого 34-летнего екатерининского этапа российской истории значительно менялась. Первое место по частотности занимает запятая (в среднем 58,03\%), однако в I период практически одинаковая частотность у запятой и двоеточия. Точка с запятой становится вторым по частотности знаком после запятой начиная с 1780-х гг., однако затем она используется почти в два раза реже. Точка как финальный знак препинания используется минимально - фиксируем всего 48 случаев (для сравнения: в корпусе отмечаем 115 употреблений точки в качестве знака сокращения).

Диаграмма 1 делает наглядными резкие изменения в употреблении запятой (рост в 2 раза), двоеточия (падение более чем в 6 раз) и сроки (падение в 2,3 раза). 
Таблица 2. Количественные характеристики материала исследования в диахроническом аспекте

\begin{tabular}{|c|c|c|c|c|c|c|c|c|c|c|c|c|}
\hline \multirow{4}{*}{ № } & \multirow{4}{*}{ Период } & \multicolumn{3}{|c|}{ Текстов } & \multicolumn{8}{|c|}{ Пунктуационных знаков } \\
\hline & & \multirow{3}{*}{ всего } & $3 \Pi-$ & $3 \Pi+$ & всего & , & : & $: \mid$ & ; & - &. $\mid$ и ..|. & $?$ и ! \\
\hline & & & абс.ч. & абс.ч. & абс.ч. & абс.ч. & абс.ч. & абс.ч. & абс.ч. & абс.ч. & абс.ч. & абсс.ч. \\
\hline & & & $\%$ & $\%$ & $\%$ & $\%$ & $\%$ & $\%$ & $\%$ & $\%$ & $\%$ & $\%$ \\
\hline \multirow[b]{2}{*}{ I } & \multirow{2}{*}{ 1762-1769 гг. } & \multirow[b]{2}{*}{89} & 3 & 57 & נJנJ & 113 & 116 & 63 & 26 & 6 & 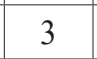 & - \\
\hline & & & 35,9 & 64,1 & 100 & 35,74 & 34,83 & 18,92 & 7,81 & 1,8 & 0,9 & - \\
\hline \multirow{2}{*}{ II } & \multirow{2}{*}{$1770-1779$ гг. } & \multirow{2}{*}{104} & 13 & 91 & 860 & 495 & 165 & 54 & 107 & 33 & 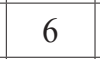 & - \\
\hline & & & 12,5 & 87,5 & 100 & 57,56 & 19,19 & 6,28 & 12,44 & 3,83 & 0,7 & - \\
\hline \multirow{2}{*}{ III } & \multirow{2}{*}{ 1780-1789 гг. } & \multirow{2}{*}{113} & 15 & 98 & 1110 & 646 & 175 & 53 & 221 & 2 & 10 & $3(?)$ \\
\hline & & & 13,3 & 86,7 & 100 & 58,2 & 15,77 & 4,77 & 19,9 & 0,18 & 0,91 & 0,27 \\
\hline \multirow{2}{*}{ IV } & \multirow{2}{*}{ 1790-1796 гг. } & \multirow{2}{*}{75} & 11 & 64 & 554 & 398 & 31 & 45 & 58 & 7 & 12 & $3(!)$ \\
\hline & & & 14,6 & 85,4 & 100 & 71,84 & 5,59 & 8,12 & 10,47 & 1,26 & 2,18 & 0,54 \\
\hline & \multirow{2}{*}{ иТОГО } & \multirow{2}{*}{381} & 71 & 310 & 2857 & 1658 & 487 & 215 & 412 & 48 & 31 & 6 \\
\hline & & & 18,6 & 81,4 & 100 & 58,03 & 17,04 & 7,52 & 14,42 & 1,68 & 1,1 & 0,21 \\
\hline
\end{tabular}

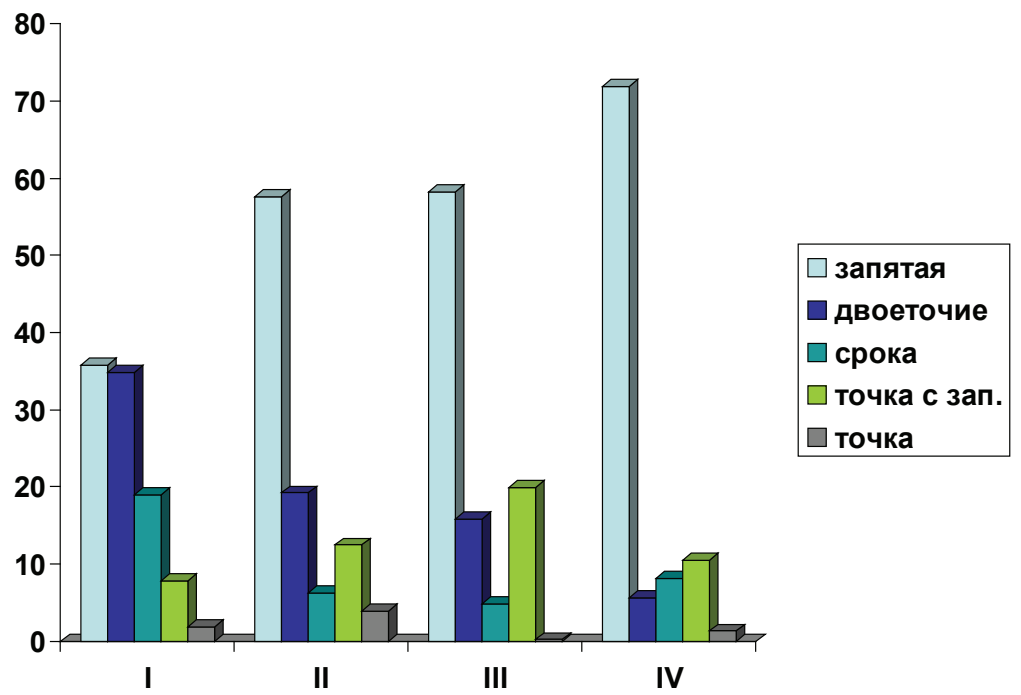

Диаграмма 1. Характеристика периодов по соотношению знаков препинания

Таким образом, первый период можно назвать периодом двоеточия, последний - периодом запятой. Более наглядно изменения в частотности употребления каждого из семи знаков представляет диаграмма 2. 
Количественные изменения становятся следствием изменений функциональных, результатом перераспределения имевшихся прежних функций и появления новых.

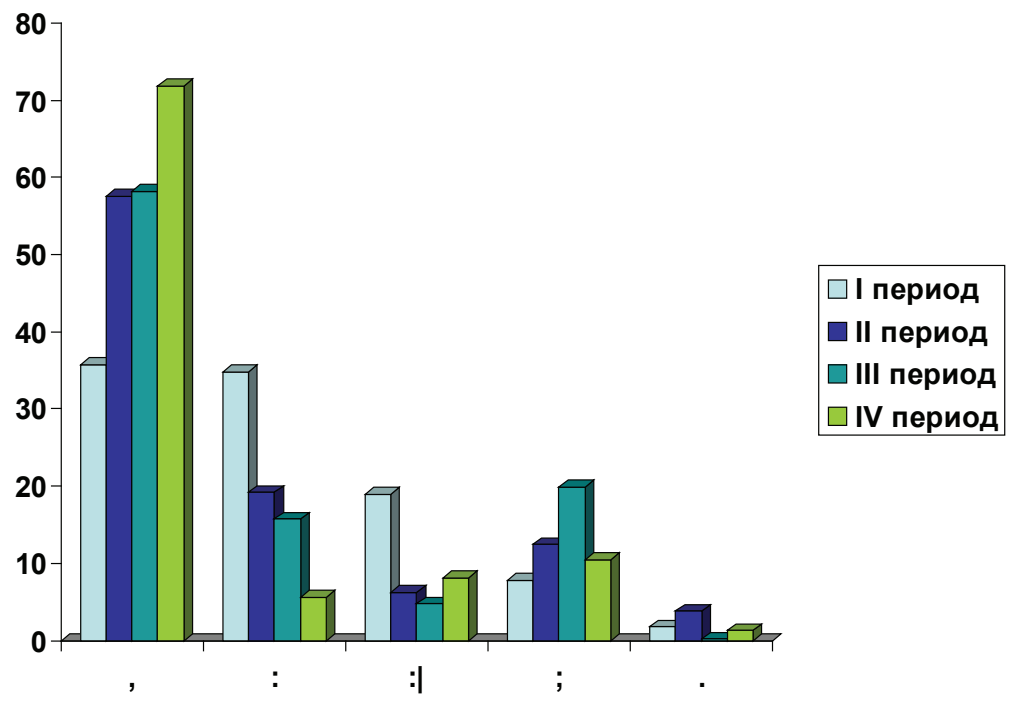

Диаграмма 2. Изменение частотности знаков препинания в течение 34 лет

\section{Количественные характеристики корпуса в жанровом аспекте}

Исследование показало, что:

1) просительные документы (доношения, челобитные) отмечены наибольшим числом «беззнаковых» текстов. Самой высокой $(27,3 \%)$ долей характеризуются челобитные, формуляр которых был предельно формализован, что закреплялось «Формой о титулах Императрицы Екатерины II» в указе № 11.590 от 2 июля 1762 г. [Polnoe 1830: 6-8];

2) каждая четвертая текстовая реализация жанров доношение, рапорт и подписка (просительные и докладные жанры), адресанты которых представители второй и третьей групп субъектов речи, тоже не имеет знаков препинания. Каждое пятое определение и промемория, также обнаруживающие устойчивый формуляр и представляющие собой жанры вторичных документов, не имеющих адресатов (остающихся в делах канцелярии) или же адресованные «рядоположенным» коллегиальным адресатам (из канцелярии - в канцелярию), также отличается 
отсутствием знаков препинания. Следовательно, причиной «беззнаковости» документа могли выступать дискурсивые особенности деловой коммуникации;

3) в то же время все документы таких распорядительных жанров, как ордер, предложение, составленные в губернских и военных канцеляриях от имени высших должностных лиц (из первой группы субъектов речи) профессиональными субъектами письма и содержащие преимущественно новую, «рематическую», неизвестную для адресата информацию - актуальное волеизъявление, имеют знаки препинания. Это самые пунктуационно насыщенные документы;

4) точка как финальный знак препинания абсолютно не представлена в четверти документных жанров, преимущественно докладных. Функцию точки в них мог выполнять знак .|, чаще всего фиксируемый в подписках;

5) предпочтение запятой характерно для всех документных жанров, хотя и в разной мере (от $85,4 \%$ в предложениях до $42,3 \%$ в челобитных), за исключением внутриканцелярских копий с журнала $(23,1 \%)$, в которых абсолютно преобладает двоеточие $(59,6 \%)$ и достаточно высока доля сроки (15,5\%). Употребление точки с запятой отличается минимальным разбросом в количественных показателях среди всех знаков.

Наглядное представление о соотношении в употреблении этих четырех знаков препинания в анализируемых документных жанрах дают диаграммы За и $3 б$.

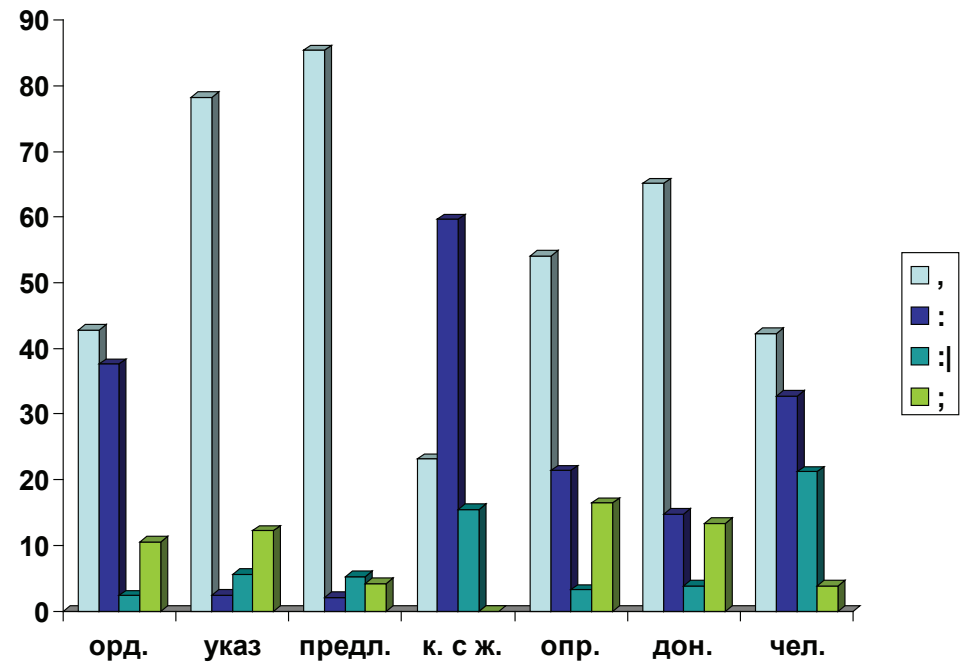

Диаграмма 3а. Жанровая корреляция в употреблении знаков препинания (распорядительные и просительные документы) 


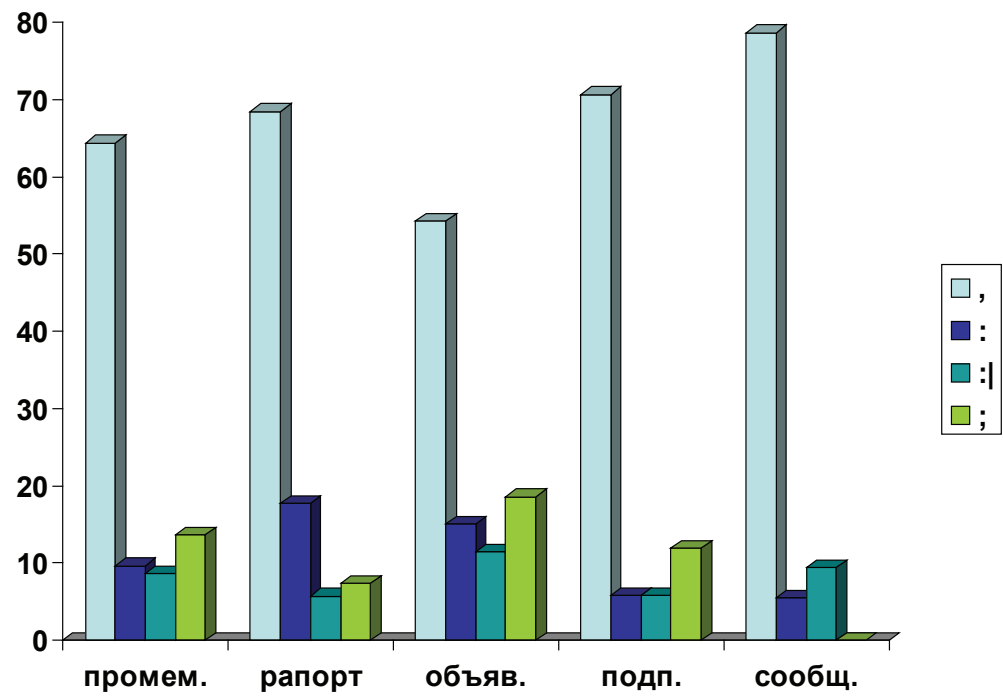

Диаграмма 3б. Жанровая корреляция в употреблении знаков препинания (докладные документы)

Диаграммы демонстрируют тот факт, что докладные документы отличаются от распорядительных и просительных бо́льшим однообразием в соотношении употребления разных знаков препинания, однако о выраженной корреляции на анализируемом ограниченном корпусе говорить не приходится. Достаточно общее наблюдение может быть сформулировано таким образом: чем ближе деловой текст к замкнутому в стенах канцелярии, с ограниченным числом субъектов профессиональной коммуникации, внутриканцелярскому документообороту, к утвержденному и тиражируемому жесткому формуляру, тем, во-первых, он более «свободен» от знаков препинания и, во-вторых, тем чаще фиксируется в нем двоеточие и срока и реже - запятая.

\section{Формулярный и грамматический аспекты анализа}

Для получения представления о пунктуации документов в целом приведем один из них в виде таблицы, что позволит увидеть грамматический каркас документа, имеющего четыре реквизита: «Текст» (сложная синтаксическая конструкция с союзной и бессоюзной связью, состоящая из 18 предикативных частей), «Подписи», «Дата», «Резолюция»; в третьей колонке представлена нумерация пунктуационных блоков (далее - ПБ), коррелирующих с субъектной и модальной организацией текста. 
Таблица 3. Определение Тюменской воеводской канцелярии о денежном обороте и разных монетах. 13 марта 1773 г. [Trofimova 2002a: 282]

\begin{tabular}{|c|c|c|}
\hline 1 & $\begin{array}{l}\text { По указамъ ея јмператорскаго величества из Сибирскои } \\
\text { губернской канцелярій; и по ордеря }[\ldots] \text { сибирскаго } \\
\text { губернатора }[\ldots] \text { Чичерина }[\ldots] \text { на јмя здешняго воеводы } \\
{[\ldots] \text { Тихомирова }[\ldots] \text { велено оставшие }[\ldots] \text { денги }[. . .]} \\
\text { старатца переводй }^{\text {ть }}[\ldots] \text { в горо Екатеринбгрхъ в тамошнъе } \\
\text { камисарство: }\end{array}$ & I \\
\hline 1 & $\mathbf{a}$ & \multirow[t]{7}{*}{ II } \\
\hline 2 & 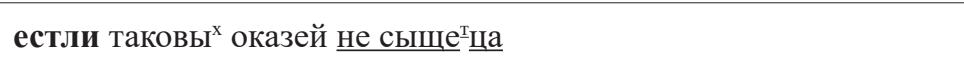 & \\
\hline 1 & 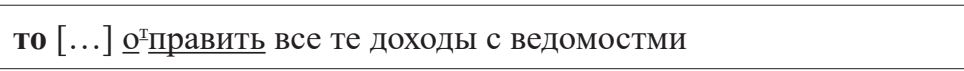 & \\
\hline 3 & какихъ сколко зборо & \\
\hline 1 & $\mathbf{j}$ & \\
\hline 4 & сколко $[\ldots] \underline{\mathrm{o}}^{\mathrm{T}} \underline{\underline{p} а в л е н о}$ будетъ & \\
\hline 1 & $\begin{array}{l}\text { его превосходителств ј в Сибирскљю губернскую канцелярію } \\
\text { репортовать; }\end{array}$ & \\
\hline 5 & 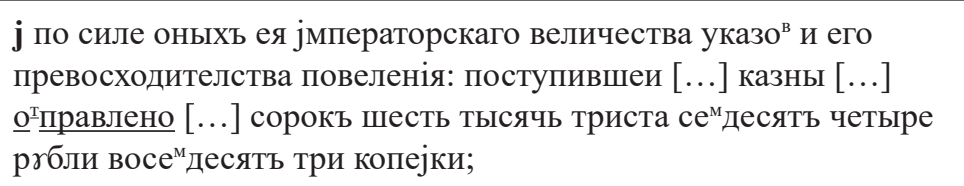 & III \\
\hline 6 & 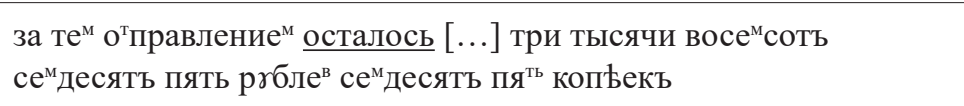 & \multirow[t]{4}{*}{ IV } \\
\hline 7 & $\begin{array}{l}\text { потомд что состоятъ онія колыванскою монетою } \\
\text { и екатеринбурскими гривенниками и четырекопеешниками }\end{array}$ & \\
\hline 8 & $\begin{array}{l}\text { также и други }{ }^{\mathrm{x}} \text { зборо } \\
\text { монетою }[\ldots] \text { казна остала }^{\mathrm{c}} \text { вся прописанною }\end{array}$ & \\
\hline 9 & и замены учинить было не ис чего; & \\
\hline 10 & 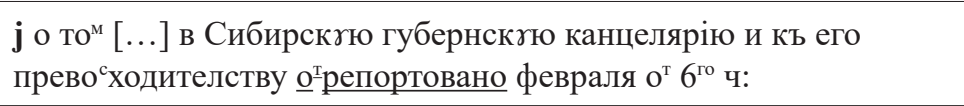 & $\mathbf{V}$ \\
\hline 11 & 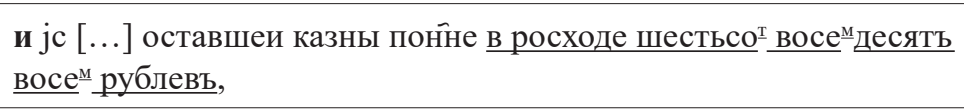 & \multirow[t]{3}{*}{ VI } \\
\hline 12 & $\begin{array}{l}\text { выменено на гдрственныя асигнаціи тысяча двести пятдесятъ } \\
\text { рублевъ }\end{array}$ & \\
\hline 13 & 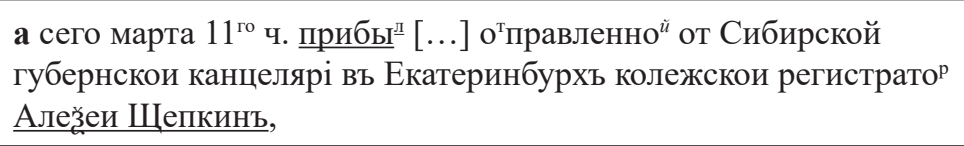 & \\
\hline
\end{tabular}




\begin{tabular}{|c|c|c|}
\hline 14 & 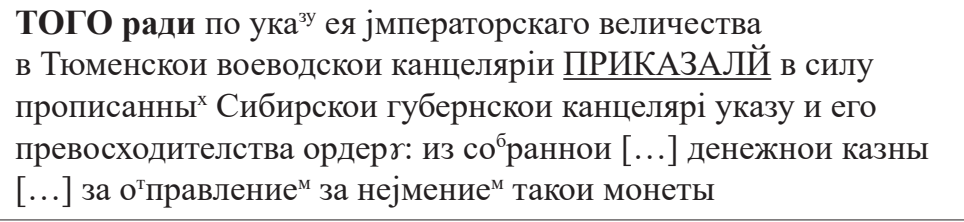 & VII \\
\hline 15 & которая хожденіе јмъетъ в Россиі, | & \\
\hline 14 & 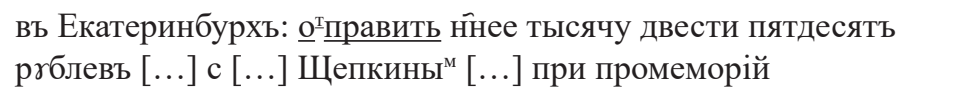 & \\
\hline 16 & $\begin{array}{l}\text { о }^{\mathrm{T}} \text { котораго требовать по полтчені той казны причислить к }[\ldots] \\
\text { сум }^{\mathrm{M}} \text {; } \\
\text { j о то } \\
\end{array}$ & \\
\hline 14 & и тое казну записать $[. .$.$] в росходъ по збора { }^{\mathrm{M}}$ & \\
\hline 17 & 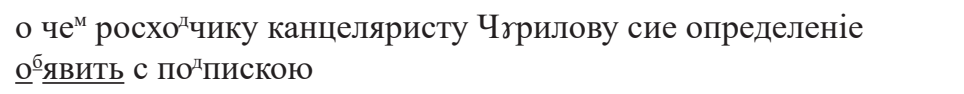 & \\
\hline 14 & 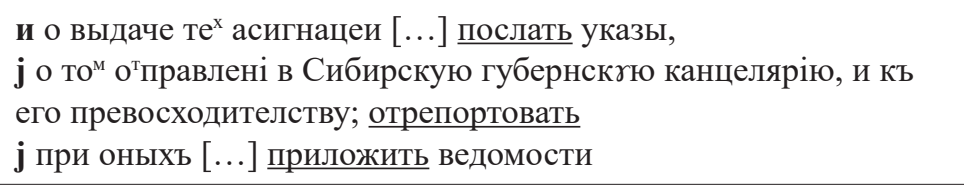 & \\
\hline \multirow[t]{5}{*}{18} & $\underline{\text { какихъ та казна зборо}}{ }^{\underline{B}} .\left.\right|^{*}$ & \\
\hline & Михаила Тихомиров ${ }^{\text {* }}$ Степа ${ }^{\text {н }}$ Аксюти ${ }^{\text {н* }}$ & \multirow[t]{3}{*}{ VIII } \\
\hline & Подписано марта 13 дня 1773 го ${ }^{\text {ду }}$ | * & \\
\hline & Секретарь Яков Нестеро & \\
\hline & По сему определению промемория и ғказы посланы [...] & IX \\
\hline
\end{tabular}

Опираясь на имеющиеся знаки препинания, рассмотрим смысловые отношения в тексте. Казусная часть документа (предикативные части 1-13):

- часть 1 (ПБ I-ІІ): названы документы двух субъектов волеизъявления (губернская канщелярия - указ, губернатор - ордер), точкой с запятой отмечена граница сфер их полномочий. К предикативному причастию велено примыкает объектным инфинитивом стараться переводить с зависимыми словами - содержание волеизъявления; его конец отмечен двоеточием. ПБ II - до точки с запятой - заканчивается инфинитивом репортовать, вводящим придаточное изъяснительное 4. Содержание блока определяется инфинитивным сочетанием отправить с ведомостями, реализация которого возможна при определенных обстоятельствах (придаточные условное и изъяснительное, 2 и 3). Дискуссионна для блока 1-4 характеристика синтаксической функции инфинитивов: 
дополнения в структуре распространенного простого предложения или же инфинитивные предикативные единицы со значением ирреальной модальности в структуре сложного;

- часть 5 (ПБ ІІІ) имеет, во-первых, двоеточие после упоминания входящих документов на границе с информацией о предопределенных ими действиях адресата; во-вторых, закрывающую её точку с запятой как знак исчерпанности волеизъявления адресанта действиями адресата, «превращения» ирреальной модальности в реальную $($ отправить $\rightarrow$ отправлено);

- в частях 6-9 (ПБ IV) сообщается о неполной реализации входящего волеизъявления в связи с особыми обстоятельствами (отправлено $\rightarrow$ отправлением $\rightarrow$ осталось $\rightarrow$ потому что...); точка с запятой выступает знаком законченности ситуации;

- часть 10 (ПБ V), имеющая в окончании двоеточие (возможно, что с дополнительным значением традиционного для документов сокращения слова число), свидетельствует об информировании о сложившейся ситуации обоих адресантов;

- части 11-13 (ПБ VI), заканчивающие казусную часть документа, сообщают о положении дел в сфере действий как адресата (в росходе, выменено), так и одного из адресантов (отправленный от). Их дальнейшее объединение в формате реальности имеет все основания ( $n p u$ был), но его необходимо сформулировать в продолжении документа (в последующей прагматической части). Граница частей обозначена скрепой ТОГО ради с предшествующей ей запятой.

Далее адресат (вновь со ссылкой на документы адресанта, отграниченные от его сферы двоеточием), принимающий на себя функцию волеизъявителя, формулирует программу действий, как в части 1, посредством инфинитивных конструкций, зависящих от формы ПРИКАЗАЛИ (предикативные части 14-18; ПБ VII). Следующее двоеточие разграничивает случившиеся события (представленные формами причастия СВ прошедшего времени собранной и девербативом за отправлением) и события желаемые, которые должны быть реализованы посредством разных субъектов действия, становящихся адресатами формулируемого приказа (отправить, требовать (причислить, уведомить), записать, объявить, послать, отрепортовать, приложить). Вероятно, знаки точка с запятой и запятая, не вполне последовательно использованные в прагматической части с сочинительной или бессоюзной связью компонентов, должны разграничивать сферы действий этих разных субъектов.

Обратим внимание: знаков препинания нет на границе с придаточными, вводимыми союзными словами (которая, от котораго, о чем, каких), например, монеты которая (части 14/15), регистратором Щепкиньм от котораго 
(части 14/16). Эти два примера входят в число 155 употреблений разных форм относительного местоимения который в функции союзного слова в первых 125 документах корпуса. Пунктуационный знак перед который находим всего в 16 случаях: в 9 перед ним стоит запятая, в 4 - срока, в 2 - двоеточие и в 1 - точка с запятой; следовательно, в $89,7 \%$ случаев, как и в приведенных выше, знака нет.

Отсутствие запятой перед союзом $\boldsymbol{a}$ в конце части 12 тоже достаточно частотно для корпуса. Проиллюстрировать неустойчивость в пунктуационном оформлении текстов корпуса может, в частности, тот факт, что из 1237 случаев употребления в текстах корпуса союза $\boldsymbol{a}$ только в 296 случаях $(23,9 \%)$ позиция отмечена знаком препинания, при этом запятой - 220, точкой с запятой -42 , двоеточием - 34; например, в выписке из следственного дела 1764 г., в описании сел и деревень, расположенных около Тюмени, 1783 г. или допросе 1789 г.:

[...] o о $^{6}$ ратно обеща $[\ldots]$ и по приказанию городничего во удоволствие получйлй все бывшие работники приготовленные на пять дощениковъ 130 чллвкъ каждой по одному рублю оть прикащика Лукй Полюгова: а послее известились [...];

[...] имеютъ кажевенное ремесло; а всеи тои неудобнои по пашню земли; со

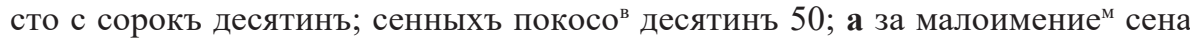
кортомятъ; [...] [Trofimova 2002a: 42, 258, 130].

Таким образом, обнаружено, что определяющим для субъектов делового письма был не грамматический, но формулярный, семантический принцип постановки знаков препинания, отражающий в документе смену субъектов речи и, как правило, изменение модальной перспективы текста.

\section{Выводы}

Проведенное исследование позволило обнаружить:

1) изменения в частотности употребления всех знаков препинания;

2) некоторую корреляцию пунктуации с жанром документа: отсутствие пунктуационного сопровождения, характерное для документов, в которых устойчивый формуляр, прецедентность отраженных экстралингвистических ситуаций, а также набор типовых синтаксических конструкций исключает ситуацию разночтений на синхронном уровне;

3) преимущественное употребление знаков препинания на композиционно-формулярных границах внутри документа при смене реквизитов и текстовых фрагментов, относящихся к разным субъектам речи и/или 
разным субъектам действия, а также при разграничении текстовых фрагментов с реальной модальностью и модальностью побуждения;

4) полифункциональность знаков препинания в случае их употребления в соответствии с интонационно-грамматическим принципом, что отражает естественность процесса формирования русских пунктуационных правил;

5) сосуществование различных пунктуационных практик в пределах одной канцелярской школы.

Ситуация вовлеченности в деловую коммуникацию к концу XVIII в. большего, в сравнении с серединой столетия, числа субъектов письма, получивших начальное образование и опыт работы с исходящими из столицы государства «образцовыми» деловыми текстами, которые тиражировались типографским способом, имела следствием формирование пунктуационной ситуации, более «продвинутой» к современным нормам, что и демонстрируют в своем большинстве документы 1790-х гг.

\section{Литература}

Kuz'minova E. (ed.), 2000, Grammatika Lavrentiâ Zizaniâ y Meletiâ Smotrickogo, Moskva: Izdatel'stvo MGU.

Polnoe sobranie zakonov Rossijskoj Imperii, s 1649 goda, 1830, vol. VI, 1720-1722, Sankt-Peterburg: Tipografiâ II Otděleniâ Sobstvennoj Ego Imperatorskago Veličestva kancelarii.

Rossijskaâ grammatika Mihaila Lomonosova, 1755, Sankt-Peterburg: pri Imperatorskoj akademii nauk, http://www.runivers.ru/bookreader/book192769/\#page/60/mode/1up; 1.07.2021.

Sobornoe uloženie, 1649, https://dlib.rsl.ru/viewer/01002429078\#?page=143; 1.07.2021. Šapiro A., 1955, Osnovy russkoj punktuacii, Moskva: Izdatel'stvo Akademii nauk.

Šubina N., 2006, Punktuaciâ sovremennogo russkogo âzyka, Moskva: Izdatel'skij centr «Akademiâ».

Trofimova O., 2002a, Tûmenskâ̂ delovâ̂ pis'mennost'. 1762-1796 gg.: Kniga II. Pamâtniki tûmenskoj delovoj pis'mennosti. Iz fondov Gosudarstvennogo arhiva Tûmenskoj oblasti, Tûmen': Izdatel'stvo Tûmenskogo universiteta.

Trofimova O., 2002b, Tûmenskâ̂ delovaâ pis 'mennost'. 1762-1796 gg.: Kniga II. Tûmenskie rukopisnye delovye teksty 1762-1796 gg. v aspektah lingvistiki i dokumentovedeniâ: lingvističeskij analiz teksta, Tûmen': Izdatel'stvo «Vektor Buk».

Trofimova O., 2014, Russkij dokument XVIII veka: punktuaciâ rukopisnogo originala i transliterirovannoj ego publikacii, Annales Universitatis Paedagogicae Cracoviensis. Studia Russologica VII (2014), folia 179, pp. 57-71.

Uspenskij B., 1975, Pervaâ russkaâ grammatika na rodnom âzyke, Moskva: Nauka. Valgina N., 1979, Russkaâ punktuaciâ: principy i naznačenie, Moskva: Prosveŝenie. Živov V., 2017, Istoriâ âzyka russkoj pis'mennosti, vol. I, Moskva: Universitet Dmitriâ Požarskogo. 